\title{
The first report of Toxoplasma gondii antibodies in free-living European bison (Bison bonasus bonasus Linnaeus)
}

\author{
Anna C. Majewska ${ }^{1}$, Anna Werner ${ }^{1}$, Władysław Cabaj ${ }^{2}$ and Bożena Moskwa ${ }^{2}$ \\ ${ }^{1}$ Department of Biology and Medical Parasitology, Faculty of Medicine I, Poznań University of Medical Sciences, Poznań, Poland; \\ ${ }^{2}$ Witold Stefański Institute of Parasitology of the Polish Academy of Sciences, Warszawa, Poland
}

\begin{abstract}
Toxoplasma gondii Nicolle et Manceaux, 1908 is an apicomplexan parasite with a worldwide distribution. It is of great medical and veterinary importance because it may cause abortion or congenital disease in its intermediate hosts, including man. The European bison, the largest herbivorous animal in Europe, is a species that has been saved from extinction. Twentyfour of 95 examined sera of the European bison (Bison bonasus bonasus) from the Białowieża Forest, Poland collected from 2008 to 2011 were found to be positive for the presence of $T$. gondii-specific $\operatorname{IgG}$ antibodies using a direct agglutination test, with the antibody titre in positive animals ranging from 40 to 18000 . Statistically significant differences were observed only between years of sample collection. This is the first report on T. gondii in lowland European bison living in the natural environment.
\end{abstract}

Keywords: Apicomplexa, serological survey, IgG antibodies, agglutination test, Białowieża Forest, Poland

The European bison is the largest herbivorous animal in Europe and is protected both by international and national laws. Most bison live in European countries (European Bison Pedigree Book 2009), with the largest individual population, comprising about 500 individuals, in the Białowieża Forest, which is the last ancient primeval woodland in Europe (Okołów et al. 2009), covering $1500 \mathrm{~km}^{2}$ in Poland and Belorussia. Although the European bison is a species that has been saved from extinction, there are still many threats to the survival of the species, in particular, its restricted gene pool and health problems caused by viral, bacterial and parasitic diseases (Pucek et al. 2004).

Toxoplasma gondii Nicolle et Manceaux, 1908 is an apicomplexan parasite with worldwide distribution. As it may cause abortion or congenital disease in its intermediate hosts, it is of great medical and veterinary importance (Dubey and Beattie 1988, Tenter et al. 2000). Domestic and wild felids are the definitive hosts of $T$. gondii, whereas humans and warm-blooded animals, including many species of mammals and birds, serve as intermediate hosts. These mainly become infected by (1) ingesting food or water contaminated with oocysts excreted with feline feces; (2) eating raw or undercooked meat containing cysts; or (3) congenital infection. Toxoplasma infection has commonly been reported in humans and a variety of species of livestock, pets, wild and zoo animals (reviewed by Tenter et al. 2000). Although there is no evidence that $T$. gondii infection occurs in the wild European bison, T. gondii antibodies have been detected in the serum of animals bred in zoological gardens (Sedlák and Bártová 2006).

The aims of the present study were to determine (1) the seroprevalence of $T$. gondii in free-living European bison from the Białowieża Forest, Poland, and (2) the relationship between antibody prevalence and sex and age of hosts and year of collection.

A total of 95 sera collected from European bison in the years 2008 to 2011 were examined. The animals were either immobilized for veterinarian treatment $(n=10)$ or shot during selective hunting seasons in the Białowieża Forest $(\mathrm{n}=85)$. Bison shooting was carried out according to a decision made by the Director General of Environment Protection (DOP-OZGIZ). The sera from the immobilized animals were sampled once.

For serum separation, blood from the jugular vein was collected in vacutainer tubes without anti-coagulants immediately after immobilization or shooting. The blood was centrifuged at $1000 \mathrm{~g}$ for 15 minutes and sera were stored at $-20^{\circ} \mathrm{C}$ before analysis for antibodies to $T$. gondii. The animals were classified into three age groups: young $(<1$ year old), juvenile $(1-3$ years old) and adult ( $>3$ years old).

The sera were examined for the presence of $T$. gondi-specific IgG antibodies using a direct agglutination test (Toxo-Screen DA, BioMérieux SA, Marcy l'Etoile, France), according to the manufacturer's instructions. Both the negative and positive controls provided in the kit were included in each test. The sera were initially screened at $1: 40$ and $1: 4000$ dilutions. Samples that were positive at $1: 40$, but were negative at $1: 4000$ dilution, were serially diluted and retested to determine the titre. A titre of $\geq 40$ was considered indicative of $T$. gondii infection in the European bison.

Seroprevalence values were statistically analysed with respect to sampling year, gender and age. The statistical analysis was performed using the chi-square test. The differences were considered statistically significant at $\mathrm{P} \leq 0.05$.

The overall seroprevalence of $T$. gondii-specific IgG antibodies in the European bison was 25\% (24 of the 95 examined sera were positive), with the antibody titre in the positive animals ranging from 40 to 18000 (Table 1).

Most of the animals were seropositive at low serum dilutions: T. gondii-specific IgG antibodies at a serum dilution of $1: 40$ were detected in sera from 13 European bison: five females 
from 6-month- to 11-year-old, and eight males from 7-monthto 6-year-old. Seven animals were positive at the $1: 60$ serum dilution: four females from 7-month- to 20-year-old, and three males from 7-month- to 2-year-old. The serum of a 2-year-old male and a 27 -year-old female reacted at the $1: 180$ serum dilution. The highest antibody titres of 1620 and 18000 were detected in the sera from a 17-year-old female and a 4.5-year-old male.

However, no statistically significant differences were observed in the prevalence of $T$. gondii antibodies with regard to the age group $\left(\mathrm{P}=0.446, \chi^{2}=1.614, \mathrm{df}=2\right)$ nor gender $(\mathrm{P}=0.853$, $\chi^{2}=0.03, \mathrm{df}=1$ ) of the animals examined (Table 2 ). Statistically significant differences in the seroprevalence of $T$. gondii in the European bison were observed only between years of sample collection $\left(\mathrm{P}=0.017, \chi^{2}=10.202, \mathrm{df}=3\right)$ : the seroprevalence among sampling years varied from 0 to $41 \%$ (Table 2 ). The highest $T$. gondii seroprevalence was observed in 2008 (41\%), whereas all sera examined in 2010 were negative.

The results of the present study indicate that the European bison from the Białowieża Forest in Poland have been exposed to T. gondii infection. To our knowledge, this is the first report on T. gondii seroprevalence in lowland European bison living in a natural environment. Previously, $T$. gondii antibodies with a titre ranging from 160 to 2560 were detected in the sera of four zoo-bred European bison (Sedlák and Bártová 2006) examined for $T$. gondii antibodies by an indirect fluorescence antibody test with a species-specific conjugate (anti-bovine $\operatorname{IgG}$ ).

Some data exist the seroprevalence of $T$. gondii in the American bison (Bison bison), the species most closely related to the European bison. The prevalence of $T$. gondii antibodies in the American bison from Alaska was 1\% (Zarnke et al. 2000) and $2 \%$ in those from Montana (Dubey 1985). Toxoplasma gondii antibodies were also detected in six of nine tested American bison from a Zoo in the Czech Republic (Sedlák and Bártová 2006). Cysts of T. gondii were also found to persist only in the liver of an experimentally-infected American bison, based on bioassays in cats and mice (Dubey 1983).

The combination of the low seroprevalence of $T$. gondii in bison from Alaska and Montana, together with the persistence of parasite cysts only in the liver of experimentally-infected bison, indicates that the American bison may be resistant to T. gondii infection or may eliminate the parasite from most of their tissues. For these reasons, the American bison is considered to be a relatively resistant host (Dubey 1983, 1985, Zarnke et al. 2000).

In the present study, the overall seroprevalence of $T$. gondii in the European bison was high (25\%). A comparison of the results from different studies is difficult due to variation in serological techniques and cut-off values as well as other factors such as different environmental and climatic conditions, immunity status, or the susceptibility of the species to infection. Nevertheless, it would be reasonable to assume that a high seroprevalence of T. gondii in $B . b$. bonasus from the Białowieża Forest indicates that animals have a weak resistance to the infection, which may be due to their low genetic heterogeneity.

A high seroprevalence in grazing animals can indicate environmental contamination with $T$. gondii oocysts shed by felids. However, the sources of exposure to $T$. gondii oocysts for the European bison in the Białowieża Forest are unknown. During vegetation season, the European bison utilize the plants of the forest floor and shrub layer, as well as the leaves and sprouts of trees available in the Białowieża Forest (Krasińska and Krasiński 2007).
Table 1. Toxoplasma gondii-specific IgG antibodies in the European bison.

\begin{tabular}{lccccc}
\hline & \multicolumn{5}{c}{ No. of positive sera at dilution } \\
& $1: 40$ & $1: 60$ & $1: 180$ & $1: 1620$ & $1: 18000$ \\
\hline Gender & & & & & \\
\hline Male & 8 & 3 & 1 & - & 1 \\
Female & 5 & 4 & 1 & 1 & - \\
\hline Age & & & & & \\
\hline Young $(<1$ year $)$ & 2 & 2 & - & - & - \\
Juvenile $(1-3$ year $)$ & 6 & 3 & 1 & - & - \\
Adult $(>3$ year $)$ & 5 & 2 & 1 & 1 & 1 \\
\hline Total & 13 & 7 & 2 & 1 & 1 \\
\hline
\end{tabular}

Table 2. Serum samples of the European bison positive for antiToxoplasma gondii antibodies by sampling year, gender and age.

\begin{tabular}{lccc}
\hline Category & $\begin{array}{c}\text { No. of serum } \\
\text { examined }\end{array}$ & $\begin{array}{c}\text { No. of positive } \\
\text { samples }(\%)\end{array}$ & P-value \\
\hline Sampling year & & & \\
\hline 2008 & 37 & $15(41)$ & \\
2009 & 27 & $4(15)$ & 0.017 \\
2010 & 12 & $0(0)$ & \\
2011 & 19 & $5(26)$ & \\
\hline Gender & & & \\
\hline Male & 53 & $13(25)$ & 0.853 \\
Female & 42 & $11(26)$ & \\
\hline Age & & & \\
\hline Young $(<1$ year $)$ & 21 & $4(19)$ & \\
Juvenile (1-3 year) & 30 & $10(33)$ & 0.446 \\
Adult $(>3$ year) & 44 & $10(23)$ & \\
\hline Total & 95 & $24(25)$ & \\
\hline
\end{tabular}

The only free-ranging felid in the Białowieża Forest is the Eurasian lynx, Lynx lynx (Linnaeus), but its population density is low. However, European bison are also known to feed on the meadows, pastures and cultivated fields located on the edges of the Białowieża Forest, and it is possible that these environments may be contaminated with the faeces of domestic cats. Additionally, during the winter seasons, the European bison's supplementary food consists of hay harvested from the same meadows bordering the Białowieża Forest.

As the risk of infection is mainly associated with the ingestion of parasite oocysts, the seroprevalence of $T$. gondii infection in ruminants may depend on both the presence of oocysts in the environment and its climatic conditions. Although T. gondii oocysts are very resistant to environmental factors, climatic and meteorological conditions may influence their survival.

In the present study, differences in $T$. gondii seroprevalence were detected between individual years $(P=0.017$, Table 2). There is no easy explanation for these findings. Although the Białowieża Forest is situated within a temperate climate zone, it is located in the coldest region of Poland, where the winters are long, cold and snowy, and the summers are warm. Data published by the Institute of Meteorology and Water Management - National Research Institute indicate that meteorological conditions in the Białowieża Forest did not differ significantly between years when the sera from the European bison were col- 
lected for the study (data not shown). Hence, temporal variation in the prevalence of $T$. gondii in the European bison cannot be attributed to climatic and meteorological conditions.

It is possible that the differences observed relate to the number of samples analysed in each year of the study. In 2010 only 12 serum samples were tested, while in other years the number of examined samples was higher. With such a small number of tested sera, it is possible that they would all be found negative by this technique, purely as a matter of chance. However, it cannot be excluded that some of them may be positive for IgM antibodies. Moreover, no explanation for these results is readily apparent because of the long persistence of IgG antibodies.

In the present study, no statistically significant differences were observed between the seroprevalence of $T$. gondii in bison of different sex or age (Table 1). These results indicate that regardless of gender and age, European bison are equally exposed to $T$. gondii infection. Similar data were obtained by other authors, who did not find significant differences between antibody prevalence and sex of different game species (Gauss et al. 2005, 2006, Gamarra et al. 2008, Richomme et al. 2009, Lopes et al. 2011).

It is worth noting that earlier studies by Cabaj et al. (2009, 2012) revealed the presence of specific IgG antibodies against Neospora caninum Dubey, Carpenter, Speer, Topper et Uggla, 1988 in four of the 95 B. b. bonasus sera examined in the present study. Coinfection of $T$. gondii and $N$. caninum was detected only in a 27-year-old cow. In three other $N$. caninum-positive sera (from 1-, 5.5-, and 25-year-old males), T. gondii-specific antibodies were not detected.
The presence of toxoplasmosis in European bison deserves further attention. As nothing is known about the clinical pattern of $T$. gondii infection and its influence on the reproduction of the European bison, it may be a threat to the survival of the species. Moreover, further research should also focus on the use of molecular methods to detect $T$. gondii in animal tissues, as well as to characterize $T$. gondii genotypes circulating in European bison. In addition, European bison meat containing T. gondii cysts may act as a source of toxoplasmosis for humans and for carnivorous animals, because a part of the slaughtered animals is used for human consumption and for feeding the wolf population in the Białowieża Forest.

In 1966, the International Union for the Conservation of Nature and Natural Resources (IUCN) classified the European bison as an endangered species in its Red List of Threatened Species, and the European bison in Białowieża Forest play an important role in the restitution and protection program of the species. It is worth pointing out that both the apicomplexan parasites, $T$. gondii and $N$. caninum, may cause abortion or congenital disease in its intermediate hosts. The effect of the infection of both these parasite species on the health status and conservation of the European bison should be taken into consideration.

Acknowledgements. Thanks are due to the Directorate of the Białowieża National Park for permission to carry out the studies. Special thanks are given to Jerzy Dackiewicz and Michał Krzysiak from the European Bison Breeding Centre, Białowieża National Park for their help in collecting samples.

\section{References}

Cabaj W., Bień J., Goźbzik K., Moskwa B. 2009: Neospora caninum in European bison in Poland - the current research status. In: W. Olech (Ed.), European Bison Conservation Newsletter, Stoważyszenie Miłośników Żubrów, Warszawa, 2: 102-111. (In Polish, with English summary.)

Cabaj W., Goździk K., Bień J., Moskwa B. 2012: Neospora caninum in European bison eliminated in Białowieża in 2010-2012. In: W. Olech (Ed.), European Bison Conservation Newsletter, Stoważyszenie Miłośników Żubrów, Warszawa, 5: 26-31. (In Polish, with English summary.)

Dubey J.P. 1983: Experimental infection of a bison with Toxoplasma gondii oocysts. J. Wildl. Dis. 19: 148-149.

DubEy J.P. 1985: Serologic prevalence of toxoplasmosis in cattle, sheep, goats, pigs, bison and elk in Montana. J. Am. Vet. Med. Assoc. 186: 969-970.

Dubey J.P., Beattie C.P. 1988: Toxoplasmosis of Animals and Man. CRC, Boca Raton, Florida, 220 pp.

European Bison Pedigree Book 2009. Białowieski Park Narodowy, Białowieża, $22 \mathrm{pp}$

Gamarra J.A., Cabezón O., Pabón M., Arnal M.C., Luco D.F., Dubey J.P., Cortázar C., Almeria S. 2008: Prevalence of antibodies against Toxoplasma gondii in roe deer from Spain. Vet. Parasitol. 153: 152-156.

Gauss C.B.L., Dubey J.P., Vidal D., Cabezón O., Ruiz-Fons F., Vicente J., Marco I., Lavin S., Gortazar C., Almeria S. 2006: Prevalence of Toxoplasma gondii antibodies in red deer (Cervus elaphus) and other wild ruminants from Spain. Vet. Parasitol. 136: 193-200.

Gauss C.B.L., Dubey J.P., Vidal D., Ruiz F., Vicente J., Marco I., Lavin S., Gortazar C., Almeria S. 2005: Seroprevalence

of Toxoplasma gondii antibodies in wild pigs (Sus scrofa) from Spain. Vet. Parasitol. 131: 151-156.

Krasińska M., Krasiński Z.A. 2007: The European Bison. A Nature Monograph. Mammalian Research Institute, Polish Academy of Sciences, Białowieża, 332 pp.

Lopes A.P., Sargo R., Rodrigues M., Cardoso L. 2011: High seroprevalence of antibodies to Toxoplasma gondii in wild animals from Portugal. Parasitol. Res. 108: 1163-1169.

OkoŁów C., Karaś M., Boєвот А. 2009: [Białowieża National Park. To Know. To Understand. To Protect.] Białowieski Park Narodowy, Białowieża, 240 pp. (In Polish.)

Pucek Z., Belousova I.P., Krasińska M., Krasiński Z.A., Olech W. 2004: European Bison. Status Survey and Conservation Action Plan. IUCN, Gland-Cambridge, 54 pp.

Richomme C., Aubert D., Gilot-Fromont E., Ajzenberg D., Mercier A., Ducrot C., Ferté H., Delorme D., Villena I. 2009: Genetic characterization of Toxoplasma gondii from wild boar (Sus scrofa) in France. Vet. Parasitol. 164: 296-300.

SedlÁx K., BÁrtová E. 2006: Seroprevalences of antibodies to Neospora caninum and Toxoplasma gondii in zoo animals. Vet. Parasitol. 136: 223-231.

Tenter A.M., Heckeroth A.R., Weiss L.M. 2000: Toxoplasma gondii: from animals to humans. Int. J. Parasitol. 30: 1217-1258.

Zarnke R.L., Dubey J.P., Kwok O.C.H., Ver Hoef J.M. 2000: Serologic survey for Toxoplasma gondii in selected wildlife species from Alaska J. Wildl. Dis. 36: 219-224.

Received 29 May 2013

Accepted 23 September 2013 